\title{
84. Studies on the Karyotype Differentiation of the Norway Rat. XX
}

\section{Anatomical Configuration of the Sexual Organs in the Males with the 11; Y Translocation in the NIG.III Strain Rats*)}

\author{
By Tosihide H. Yosida \\ National Institute of Genetics, Misima, Japan \\ (Communicated by Sajiro Makino, M. J. A., Sept. 12, 1985)
}

The male rat with the $11 ; \mathrm{Y}$ translocation has been found primarily in one NIG-III strain rat after $\gamma$-irradiation. This specimen was characterized by the reciprocal translocation between the autosome no. 11 and the long arm of the Y-chromosome. By such a translocation one of the no. 11 chromosomes changed into the metacentric element and the $\mathrm{Y}$ chromosome with the centromere changed into a small dot element (Yosida 1984). The male rat was mated to the normal females and many offspring were obtained. The most of the offspring had the $11 / 11 ; \mathrm{Y}$ and the $\mathrm{X} / \operatorname{dot}-\mathrm{Y}$, same as the parent male, but some males showed the other sex chromosome combinations, such as $(11 ; \mathrm{Y} / 11 ; \mathrm{Y}, \mathrm{X} / \operatorname{dot}-\mathrm{Y}),(11 / 11 ; \mathrm{Y}$, $\mathrm{X} / \mathrm{X} / \operatorname{dot}-\mathrm{Y}$ ) and some others. Only males with the $11 / 11 ; \mathrm{Y}$ and the $\mathrm{X} / \operatorname{dot}-\mathrm{Y}$ combination among them were fertile (Yosida and Hamada 1985). In order to know the cause of the sterility the males with several types of the 11 ; $Y$ translocation were operated in order to examine the male sexual organs. The present paper deals with the results of the anatomical examinations of the males, with a special reference to the development of the male organs.

Material and methods. The males of the NIG-III strain rats with several types of the $11 ; \mathrm{Y}$ translocation were mated to the normal females $(11 / 11, \mathrm{X} / \mathrm{X})$ or the fertile females with the translocation $(11 / 11 ; \mathrm{Y}, \mathrm{X} / \mathrm{X})$ in order to check the fertility of them. After the examination of the fertility, they were examined anatomically. The chromosomes of these specimens were observed from the tail cultured cells by our routine procedure (Yosida 1980). The photographs of the operated rats with the translocation were taken to compare the male organs with the normal specimen. The weight of the testis and the seminal vesicle in the males with translocation were measured. From each specimen one tesis was taken out and weighed it, and the other one testis was fixed to further examinations. The right and left seminal vesicles were taken out together, and weighed.

Results and discussion. 1) External feature of the males with the $11 ; \mathrm{Y}$ translocation: The normal adult male of the rat was easily identified from the outside by having the large scrotum between the penis and the anus. The $11 ; \mathrm{Y}$ translocation heterozygous and fertile males $(11 / 11 ; \mathrm{Y}, \mathrm{X} /$ dot-Y) had the large scrotum similar to the normal male (Fig. 1A). In the $11 ; \mathrm{Y}$ translocation homozygous males $(11 ; \mathrm{Y} / 11 ; \mathrm{Y}, \mathrm{X} / \operatorname{dot}-\mathrm{Y})$, the external feature was male, but the development of the testis was poor (Fig. 1B). In the other sex chromosome anomalies such as $\mathrm{X} / \mathrm{X} / \operatorname{dot}-\mathrm{Y}$ and $\mathrm{X} / \operatorname{dot}-\mathrm{Y} / \operatorname{dot}-\mathrm{Y}$ complexes, the development of the testis was also poor similar to the above specimens, although the external feature was male.

\footnotetext{
*) Contribution no. 1635 from the National Institute of Genetics, Japan.
} 

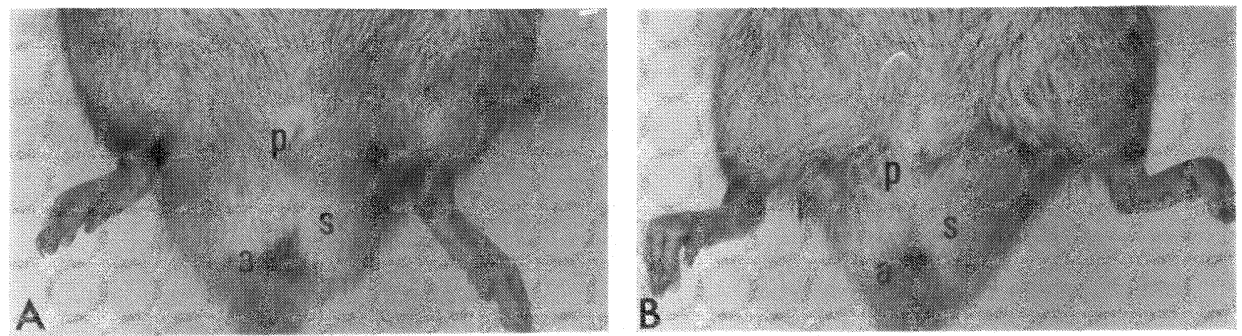

Fig. 1. External feature of the male specimens with the 11 ; Y translocation in the NIG-III strain rat. A, translocation heterozygote $(11 / 11 ; \mathrm{Y}, \mathrm{X} / \operatorname{dot}-\mathrm{Y})$. B, translocation homozygote $(11 ; \mathrm{Y} / 11 ; \mathrm{Y}, \mathrm{X} /$ dot-Y). a, anus. p, penis. s, scrotum.
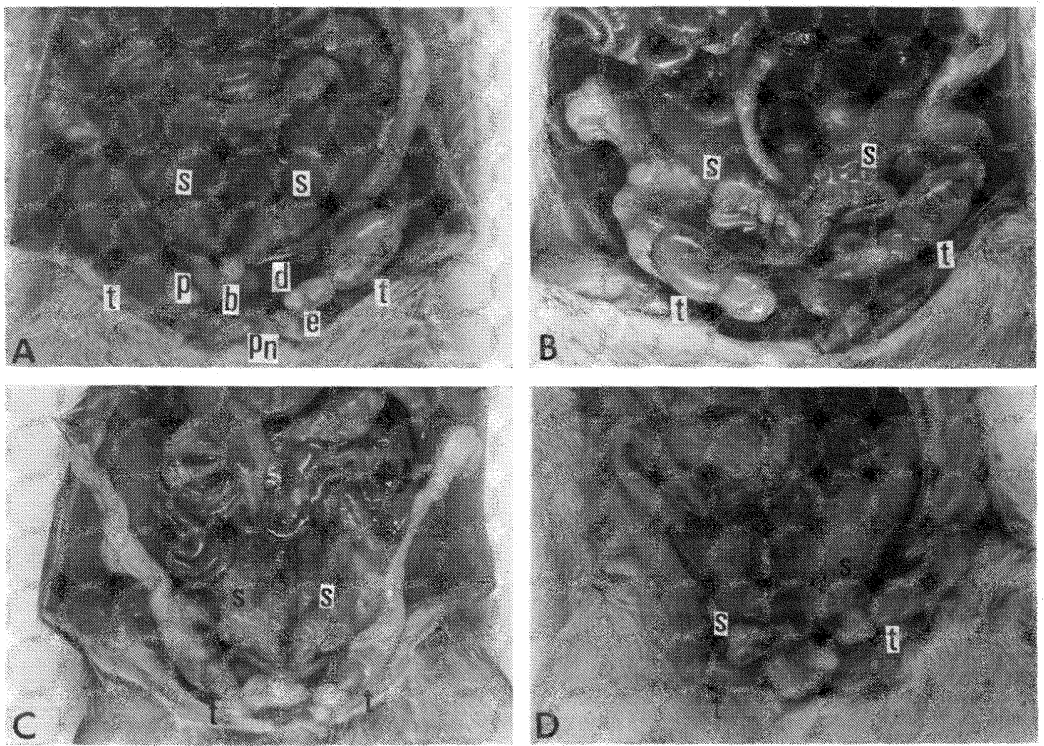

Fig. 2. Anatomical feature of the males with the $11 ; \mathrm{Y}$ translocation in the NIG-III strain rat. $A$, normal male $(11 / 11, X / Y)$. $B$, translocation heterozygote $(11 / 11 ; Y$, $\mathrm{X} /$ dot-Y). $\mathrm{C}$, translocation homozygote $(11 ; \mathrm{Y} / 11 ; \mathrm{Y}, \mathrm{X} / \operatorname{dot}-\mathrm{Y}) . \mathrm{D}$, translocation heterozygote with the double X's $(11 / 11 ; \mathrm{Y}, \mathrm{X} / \mathrm{X} /$ dot-Y). b, bladder. d, ductus deferens. e, epididymis, $p$, prostata. pn, penis. $s$, seminal vesicle. t, testis. (All photographs are taken by the same magnification.)

2) Anatomical features of the males with the $11 ; \mathrm{Y}$ translocation: In the $11 ; \mathrm{Y}$ translocation heterozygous males, the testis and the other sexual organs, such as the seminal vesicle, prostata, epididymis, ductus deferens and penis developed similar to those of the normal male with the 11/11 and the $\mathrm{X} / \mathrm{Y}$ constitution (Fig. 2, A, B). On the other hand, in the 11 ; Y translocation homozygous males the testis was smaller than those of the normal and the translocation heterozygous males, and its size was about one-third of those of the normal or the $11 ; \mathrm{Y}$ translocation heterozygous males (Fig. 2C). The other sexual organs such as the seminal vesicle, prostata, epididymid and others were observed in the translocation homozygous males, but their development was slightly poorer than that of the normal and the translocation heterozygous males.

Among 8 translocation homozygous males examined so far, the sexual organs 
of the 6 specimens developed symmetrically, but in the other 2 specimens the development of some male organs was asymmetrical. In one of them, the testis of the left side was not developed and a trace of the testis was observed. The development of the epididymis of this specimen was also very poor. The testis of the right side was observed to be similar to the other homozygous males. In the other specimen, the development of the seminal vesicle was asymmetrical, such as the development of the left vesicle was almost normal, but that of the right one was just a trace.

The specimens with the other sex chromosome anomalies such as the $\mathrm{X} / \mathrm{X} / \operatorname{dot}-\mathrm{Y}$ and the $\mathrm{X} / \operatorname{dot}-\mathrm{Y} / \operatorname{dot}-\mathrm{Y}$ were all steril. Although the testis and the other sexual organs were observed in these specimens, their development was poor as similar to the translocation homozygous male (Fig. 2D). Among the $11 ; \mathrm{Y}$ translocation heterozygous males, some specimens were the sterile as described previously (Yosida and Hamada 1985). The development of the sexual organs of these specimens was also poor as seen in the translocation homozygous males.

2) Measurement of the weight of the sexual organs: As stated above the sterile males with the $11 ; \mathrm{Y}$ translocation had a smaller testis than that of the normal males or the fertile males of the translocation heterozygotes. To know what extent the sexual organs decreased from the normal ones, the weight of the testis and the seminal vesicles were measured in the $11 ; \mathrm{Y}$ translocation males.

a) The testis: The average weight of one testis in the 3 normal and fertile males was $1.5 \pm 0.17 \mathrm{~g}$ (Table $\mathrm{I}$ ), but that in the $11 ; \mathrm{Y}$ translocation heterozygous

Table I. Weight of the testis and the seminal vesicle in the $11 ; \mathrm{Y}$ translocation males

\begin{tabular}{|c|c|c|c|c|}
\hline Sex chromosomes & $\begin{array}{l}\text { No. of } \\
\text { specimens }\end{array}$ & $\begin{array}{l}\text { Av. weight of } \\
\text { one testis } \\
(\mathrm{g})\end{array}$ & $\begin{array}{l}\text { Av. weight of } \\
\text { both seminal } \\
\text { vesicles }(\mathrm{g})\end{array}$ & Remarks \\
\hline \multicolumn{5}{|l|}{ Normal (control) } \\
\hline $11 / 11, \mathrm{X} / \mathrm{Y}$ & 3 & $1.5 \pm 0.17$ & $1.33 \pm 0.15$ & Fertile \\
\hline \multicolumn{5}{|l|}{ Heterozygotes } \\
\hline $11 / 11 ; Y, X / \operatorname{dot}-\mathrm{Y}$ & 3 & $1.46 \pm 0.32$ & $1.58 \pm 0.1$ & Fertile \\
\hline " & 1 & 0.3 & 1.0 & Sterile \\
\hline \multicolumn{5}{|l|}{ Homozygotes } \\
\hline $11 ; \mathrm{Y} / 11 ; \mathrm{Y}, \mathrm{X} / \operatorname{dot}-\mathrm{Y}$ & 8 & $0.54 \pm 0.1$ & $1.27 \pm 0.16$ & Sterile \\
\hline \multicolumn{5}{|l|}{ Other abnormalities } \\
\hline 11/11; Y, X/X/dot-Y & 2 & $0.38 \pm 0.02$ & $0.9 \pm 0.25$ & Sterile \\
\hline 11/11, X/X/dot-Y & 1 & 0.3 & 1.25 & Sterile \\
\hline $11 / 11, X / \operatorname{dot}-\mathrm{Y} / \operatorname{dot}-\mathrm{Y}$ & 1 & 0.35 & 1.5 & Sterile \\
\hline
\end{tabular}

males with the fertility was $1.46 \pm 0.32 \mathrm{~g}$ in 3 specimens. It was almost similar to the normal one. On the other hand, one sterile male with the same heterozygous translocation had the small testis and its weight was only $0.3 \mathrm{~g}$, which was rather smaller than that of the translocation homozygous males. The average weight of the testis in 8 translocation homozygous males $(11 ; \mathrm{Y} / 11 ; \mathrm{Y}, \mathrm{X} / \operatorname{dot}-\mathrm{Y})$ was $0.5 \pm 0.1 \mathrm{~g}$, which was about one-third of the normal or the $11 ; \mathrm{Y}$ translocation heterozygous and fertile males. In the 3 specimens with the $\mathrm{X} / \mathrm{X} / \mathrm{dot}-\mathrm{Y}$ sex chromosomes, the testis were weighed. Among them 2 specimens had the translocation heterozygous pair $(11 / 11 ; \mathrm{Y}, \mathrm{X} / \mathrm{X} / \operatorname{dot}-\mathrm{Y})$, but the other one had the 
normal pair no. $11(11 / 11, \mathrm{X} / \mathrm{X} /$ dot-Y). The weight of the testis in these two types was almost similar. In the former it was $0.38 \pm 0.02 \mathrm{~g}$ and in the latter, $0.3 \mathrm{~g}$. They were about one-fifth of the normally developed testis. The testis of one male with the $\mathrm{X} / \operatorname{dot}-\mathrm{Y} / \operatorname{dot}-\mathrm{Y}$, but the autosome no. 11 was the normal pair $(11 / 11)$, weighed $0.35 \mathrm{~g}$, almost the same as those of the $\mathrm{X} / \mathrm{X} /$ dot-Y specimens.

b) The seminal vesicle: In the normal males $(11 / 11, X / Y)$, the weight of the seminal vesicle, which was measured in combination of the right and left ones, was $1.33 \pm 0.15 \mathrm{~g}$ in an average of 3 specimens. The weight of the 3 heterozygous males $(11 / 11 ; \mathrm{Y}, \mathrm{X} /$ dot- $\mathrm{Y})$, however, was $1.58 \pm 0.1 \mathrm{~g}$ in average. It is interesting that the weight of the seminal vesicle in the $11 ; \mathrm{Y}$ translocation heterozygous males was larger than that of the normal one, although its reason was unknown at present. In the sterile $11 ; \mathrm{Y}$ translocation heterozygous male, the seminal vesicle weighed $1.0 \mathrm{~g}$, which was rather smaller than the fertile one. The weight of the vesicle in the $11 ; \mathrm{Y}$ translocation homozygous specimens was $1.27 \pm 0.16 \mathrm{~g}$ in an average of 8 specimens, that was slightly smaller than the normal one. In the specimens with the $\mathrm{X} / \mathrm{X} / \mathrm{dot}-\mathrm{Y}$, the seminal vesicle was slightly smaller than the normal one, but that in the specimen with the $\mathrm{X} /$ dot$\mathrm{Y} /$ dot-Y, its weight was almost normal. The weight of the testis is always corresponded to the fertility of the males; namely, the fertile males had the well developed large testis, but in the sterile males the testis was always smaller than that of the fertile one. On the other hand, the weight of the seminal vesicle was variable, and the weight was not corresponded to the fertility.

The anatomical examination of the $\mathrm{X} / \mathrm{X} / \mathrm{Y}$ male of the black rat which occurred after $\gamma$-irradiation has been carried out by Wada et al. (1984). According to them, the weight of the testis was approximately one-fourth of the normal specimen. It was $0.38 \mathrm{~g}$ in the $\mathrm{X} / \mathrm{X} / \mathrm{Y}$ male, although $1.6 \mathrm{~g}$ in the normal one. The reduction of the weight in the $\mathrm{X} / \mathrm{X} / \mathrm{Y}$ male testis was very similar to the $\mathrm{X} / \mathrm{X} /$ dot- $\mathrm{Y}$ male of the $\mathrm{NIG-III}$ strain rat. In the sterile $\mathrm{X} / \mathrm{X} / \mathrm{Y}$ mouse, the poor development of the testis has been described by Russell and Chu (1961). An extreme small testis has been observed in the sterile $\mathrm{X} / \mathrm{Y} / \mathrm{Y}$ mouse (Cattanach and Pollani 1969). Ill development of the testis has also been described by several investigators of the Kleinefelter patients (see Makino 1975). Based on the above several investigations, it is strongly suggested that the sterility of the translocation homozygous male $(11 ; \mathrm{Y} / 11 ; \mathrm{Y}, \mathrm{X} /$ dot- $\mathrm{Y})$ and the other males with the abnormal sex chromosome constitution in the NIG-III strain rats seemed to be mainly due to the poor development of the testis.

Acknowledgement. The author is grateful to Emeritus Professor Sajiro Makino, M. J. A., for his reading of this manuscript with keen interest.

\section{References}

Cattanach, B. M., and Pollard, C. E.: Cytogenetics, 8, 80-86 (1969).

Makino, S.: Human Chromosomes. Igaku Shoin, Ltd., Tokyo, 600 pp. (1975).

Russell, L. B., and Chu, E. H.: Proc. Nat. Acad. Sci. Wash., 47, 571-577 (1961).

Wada, M. Y., Suzuki, K., and Yosida, T. H.: Proc. Japan Acad., 60B, 393-396 (1984).

Yosida, T. H.: Cytogenetics of the Black Rat. Univ. Tokyo Press, Tokyo, 256 pp. (1980).

- : Proc. Japan Acad., 60B, 125-128 (1984).

Yosida, T. H., and Hamada, T.: ibid., 61B, 176-179 (1985). 